Prepared in cooperation with the Nevada Operation Office of the U.S. Department of Energy, under Interagency agreement DE-AI52-01NV13944

\title{
Micrometeorological and Soil Data for Calculating Evapotranspiration for Rainier Mesa, Nevada Test Site, Nevada, 2002-05
}

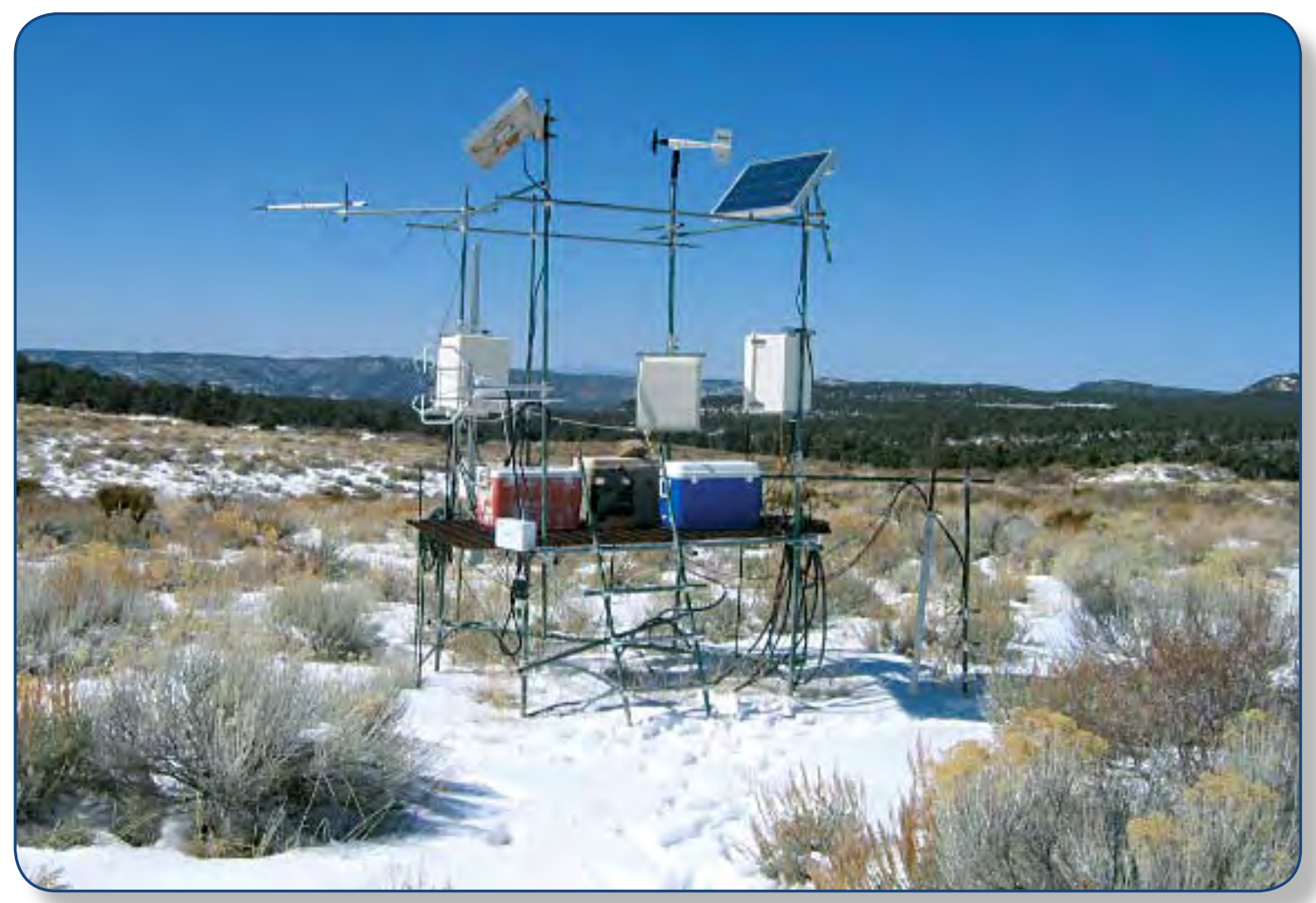

Open-File Report 2006-1312

U.S. Department of the Interior

U.S. Geological Survey 
Cover: Photograph of the Rainier Brush site looking northwest, Nevada Test Site, Nevada. (Photograph taken by Gary L. Otto, U.S. Geological Survey, date unknown.) 


\section{Micrometeorological and Soil Data for Calculating Evapotranspiration for Rainier Mesa, Nevada Test Site, Nevada, 2002-05}

By Guy A. DeMeo, Alan L. Flint, Randell J. Laczniak, and Walter E. Nylund

Prepared in cooperation with the Nevada Operation Office of the U.S. Department of Energy, under Interagency Agreement DE-AI52-01NV13944

Open-File Report 2006-1312 


\section{U.S. Department of the Interior DIRK KEMPTHORNE, Secretary}

\section{U.S. Geological Survey \\ Mark D. Myers, Director}

\section{U.S. Geological Survey, Reston, Virginia: 2006}

For product and ordering information:

World Wide Web: http://www.usgs.gov/pubprod

Telephone: 1-888-ASK-USGS

For more information on the USGS--the Federal source for science about the Earth, its natural and living resources, natural hazards, and the environment:

World Wide Web: http://www.usgs.gov

Telephone: 1-888-ASK-USGS

Any use of trade, product, or firm names is for descriptive purposes only and does not imply endorsement by the U.S. Government.

Although this report is in the public domain, permission must be secured from the individual copyright owners to reproduce any copyrighted materials contained within this report.

Suggested citation:

DeMeo, G.A., Flint, A.L., Laczniak, R.J., and Nylund, W.E., 2006, Micrometeorological and soil data for calculating evapotranspiration for Rainier Mesa, Nevada Test Site, Nevada, 2002-05: U.S. Geological Survey Open-File Report $2006-1312,12 p$. 


\section{Contents}

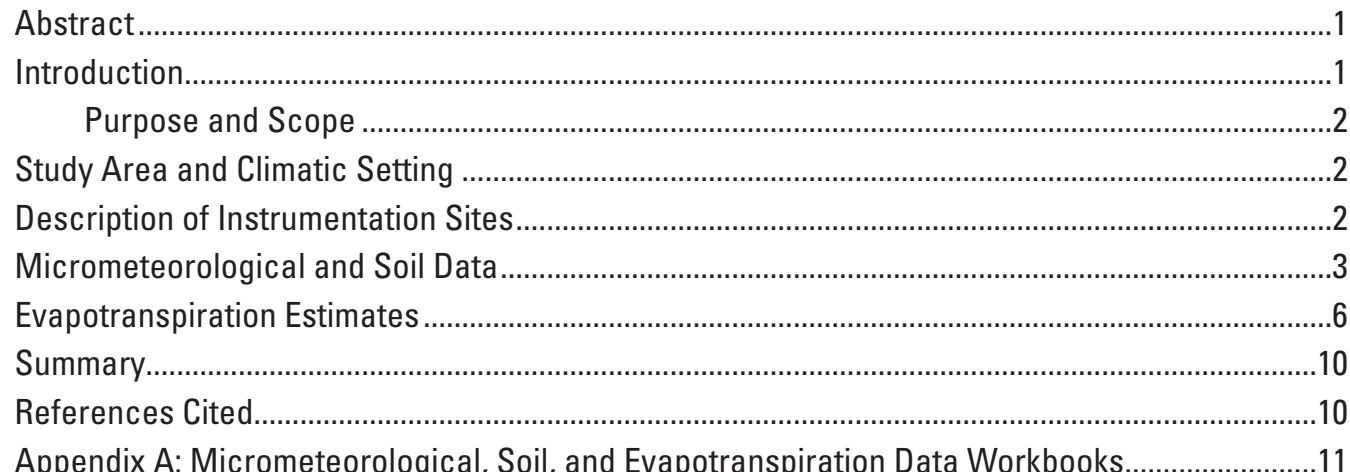

\section{Figures}

Figure 1. Map showing location of Death Valley Ground-Water Regional Flow System

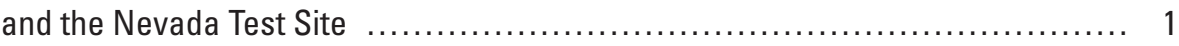

Figure 2. Map showing location of tree and brush sites, Rainier Mesa, Nevada Test Site $\ldots \quad 2$

Figure 3. Photographs of $(A)$ tree and $(B)$ brush sites, Rainier Mesa, Nevada Test Site $\ldots \ldots .3$

Figure 4. Graphs showing examples of daily average micrometeorological data collected at brush site, Rainier Mesa, Nevada Test Site, January 1, 2002 August 23, 2005

Figure 5. Schematic showing $(A)$ placement of soil-water content probes at tree and brush sites and $(B)$ vertical structure of deeper hole and placement of heatdissipation probes used at both sites, Rainier Mesa, Nevada Test Site

Figure 6. Graphs showing daily average volumetric soil-water content and daily average matric water potential at the brush site, shallow hole 1, Rainier Mesa, Nevada Test Site, January 1, 2002 - August 23, 2005

Figure 7. Graph showing total annual precipitation measured at Rainier Mesa, Nevada Test Site, 2002-05

Figure 8. Schematics of $(A)$ Bowen ratio and $(B)$ eddy covariance instrumentation used at tree and brush sites on Rainier Mesa, Nevada Test Site

Figure 9. Graphs showing daily evapotranspiration at brush and tree sites computed from data using eddy covariance and Bowen ratio methods, Rainier Mesa, Nevada Test Site, January 1, 2002 - August 23, 2005. 


\section{Tables}

Table 1. Measured parameter and manufacturer name and model number used for the Bowen ratio, eddy covariance, and soil-moisture calculations, Rainier Mesa, Nevada Test Site.

Table 2. Number of days per month that evapotranspiration rates are available during the collection period for the Bowen ratio and eddy covariance methods at the tree and brush sites, Rainier Mesa, Nevada Test Site, January 2002 August 2005

Table 3. Calculated monthly evapotranspiration at the tree and brush sites, Rainier Mesa, Nevada Test Site, January 2002 - August 2005

\section{Conversion Factors, Datum, and Symbols and Acronyms}

Conversion Factors

\begin{tabular}{lcl}
\hline Multiply & By & To obtain \\
\hline millimeter $(\mathrm{mm})$ & 0.03937 & inch $(\mathrm{in})$. \\
meter $(\mathrm{m})$ & 3.281 & foot $(\mathrm{ft})$ \\
kilometer $(\mathrm{km})$ & 0.6214 & mile $(\mathrm{mi})$ \\
square hectometer $\left(\mathrm{km}^{2}\right)$ & 247.1 & acre \\
square kilometer $\left(\mathrm{km}^{2}\right)$ & 0.3861 & square mile $\left(\mathrm{mi}^{2}\right)$ \\
cubic hectometer $\left(\mathrm{hm}^{3}\right)$ & 810.7 & acre-foot $(\mathrm{acre}-\mathrm{ft})$ \\
kilopascal $(\mathrm{kPa})$ & 0.1450 & pound per square inch $\left(\mathrm{lb} / \mathrm{in}^{2}\right)$ \\
bar & 100 & kilopascal $(\mathrm{kPa})$ \\
meter per second $(\mathrm{m} / \mathrm{s})$ & 2.237 & mile per hour $(\mathrm{mi} / \mathrm{hr})$ \\
meter per second $(\mathrm{m} / \mathrm{s})$ & 3.281 & foot per second $(\mathrm{ft} / \mathrm{s})$ \\
\hline
\end{tabular}

Temperature in degrees Celsius $\left({ }^{\circ} \mathrm{C}\right)$ may be converted to degrees Fahrenheit $\left({ }^{\circ} \mathrm{F}\right)$ as follows:

$$
{ }^{\circ} \mathrm{F}=\left(1.8 \mathrm{x}^{\circ} \mathrm{C}\right)+32 \text {. }
$$

Datum

Horizontal coordinate information is referenced to the North American Datum of 1983 (NAD 83).

Symbols and Acronyms

\begin{tabular}{cl}
\hline Symbols and Acronyms & \multicolumn{1}{c}{ Meaning } \\
\hline DVRFS & Death Valley Regional Ground-Water Flow System \\
$E$ & Rate of water evaporation \\
$\mathrm{ET}$ & Evapotranspiration \\
$G_{s}$ & Soil heat flux \\
$\mathrm{H}$ & Sensible heat flux \\
$\mathrm{HDP}$ & Heat-dissipation probe \\
NOAA & National Oceanic and Atmospheric Administration \\
NTS & Nevada Test Site \\
$R_{n}$ & Net radiation \\
USGS & United States Geological Survey \\
WCR & water-content reflectometer \\
$\lambda$ & Latent heat of vaporization for water \\
$\lambda E$ & Latent heat flux (or evaporative flux) \\
\hline
\end{tabular}




\title{
Micrometeorological and Soil Data for Calculating Evapotranspiration for Rainier Mesa, Nevada Test Site, Nevada, 2002-05
}

\author{
By Guy A. DeMeo, Alan L. Flint, Randell J. Laczniak, and Walter E. Nylund
}

\begin{abstract}
Micrometeorological and soil-moisture data were collected at two instrumented sites on Rainier Mesa at the Nevada Test Site, January 1, 2002 - August 23, 2005. Data collected at each site include net radiation, air temperature, and relative humidity at two heights; wind speed and direction; subsurface soil heat flux; subsurface soil temperature; volumetric soil water; and matric water potential. These data were used to estimate 20-minute average and daily average evapotranspiration values. The data presented in this report are collected and calculated evapotranspiration rates.
\end{abstract}

\section{Introduction}

Rainier Mesa, in the north-central part of the Nevada Test Site (NTS), is in the Death Valley Regional GroundWater Flow System (DVRFS), a major flow system in the Great Basin Regional aquifer system (Harrill and Prudic, 1998; fig. 1). Ground water in this flow system is recharged locally by precipitation that falls on high-altitude areas, such as Rainier Mesa. About 60 underground nuclear devices were detonated in tunnels within unsaturated volcanic rock beneath Rainier Mesa (U.S. Department of Energy, 2000). Radionuclides generated as a consequence of nuclear testing could be carried downward by water infiltrating from the ground surface to the water table. However, few data are available from which to characterize infiltration at Rainier Mesa. A better understanding of the distribution and rate of infiltration is necessary to evaluate the potential for migration of radionuclides.

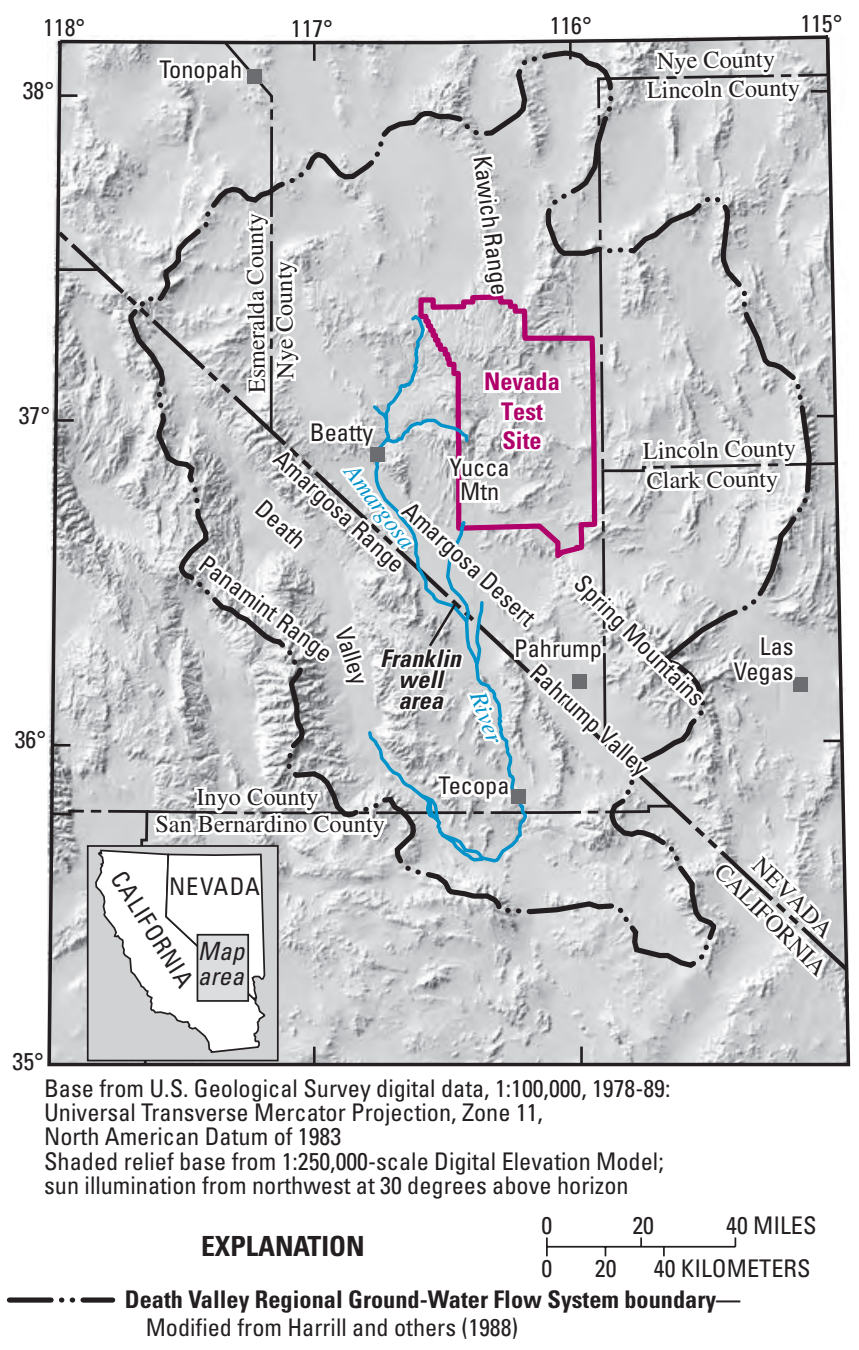

Figure 1. Location of Death Valley Regional Ground-Water Flow System and the Nevada Test Site. 


\section{Purpose and Scope}

This report documents micrometeorological and soil data collected at two instrumented sites on Rainier Mesa, NTS. Twenty-minute micrometeorological data and hourly soil-moisture data were collected from January 1, 2002, to August 23, 2005, and are summarized in Microsoft Excel workbooks (appendix A). These data were used to compute evapotranspiration (ET) rates, volumetric soil-water content, and matric water potential. Plots of daily maxima and minima atmospheric parameters, daily average volumetric soilwater content, matric water potential, and daily ET rates are provided in appendix A.

\section{Study Area and Climatic Setting}

Rainier Mesa is about $140 \mathrm{~km}$ northwest of Las Vegas, Nev. (fig. 2). The mesa covers an area of about $11 \mathrm{~km}^{2}$ and has an average altitude of 2,200 $\mathrm{m}$ (Russell and others, 2001). Vegetation on the mesa is characterized by pinyon pine (Pinus edulis) and juniper (Juniperus sp.) trees, rabbitbrush (Chrysothamnus sp.), perennial grasses, and high-desert scrub brush.

Precipitation on Rainier Mesa principally is from coolseason Pacific storms and from warm-season convective storms when moist tropical air flows northward from the southeastern North Pacific Ocean. Average annual precipitation on Rainier Mesa is approximately $330.0 \mathrm{~mm}$, much of which falls as snow. The maximum recorded annual precipitation for 1964-2005 was $682.5 \mathrm{~mm}$ in 1983 and the minimum recorded annual precipitation was $9.6 \mathrm{~mm}$ in 2002. Precipitation data and a general description of the NTS climate, which includes a discussion of the higher terrain areas representative of Rainier Mesa, are available at http://www.sord.nv.doe.gov/raingage/Monthly/Rainer_Mesa_ Monthly_Data.txt and at http://www.sord.nv.doe.gov/climate/ climate.nts.general.pdf (National Oceanic and Atmospheric Administration, 2006).

\section{Description of Instrumentation Sites}

Data-collection platforms, equipped with instrumentation that continuously measures and logs micrometeorological and soil-moisture parameters, were installed at two sites. These data were used to compute ET and also can be used to develop infiltration profiles.

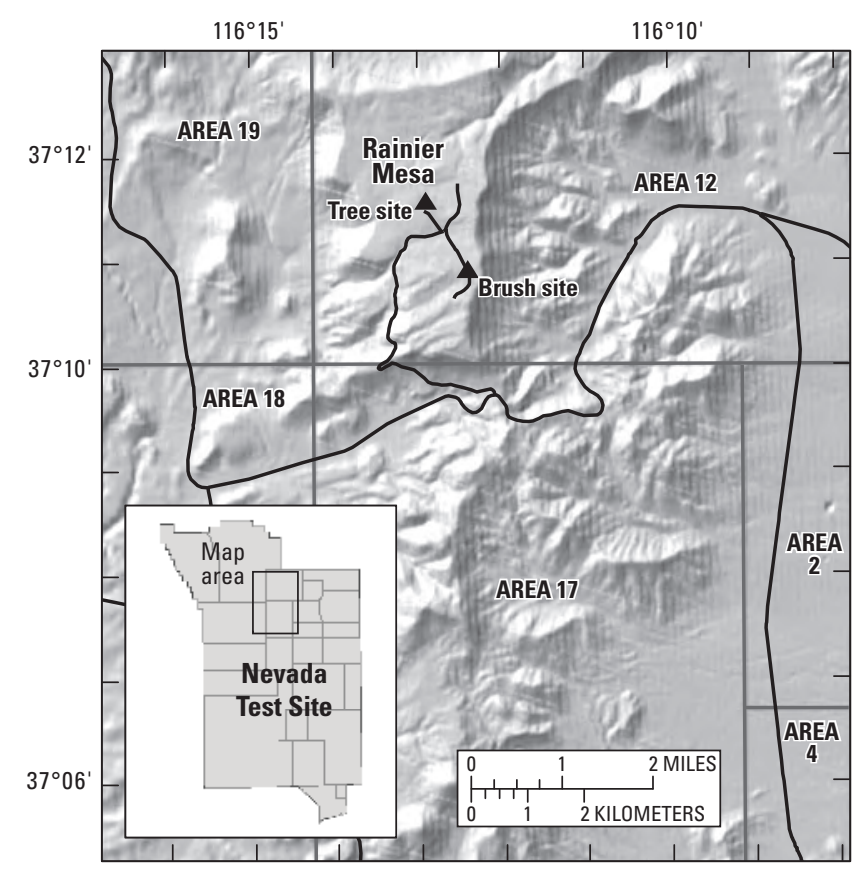

Base from USGS digital data 1:100,000 1979-89 Universal Transverse Mercator projection, Zone 11, North American Datum of 1983.

Shaded-relief base from National Elevation Data (NED); sun-illumination from northwest at 45 degrees above horizon.

Figure 2. Location of tree and brush sites, Rainier Mesa, Nevada Test Site.

One platform, referred to in this report as the tree site, is in a sparse to moderately dense pinyon and juniper forest. The site is characterized by a vegetation cover of about 20 to 30 percent (fig. $3 A$ ) and is colocated with a meteorological tower operated by the National Oceanic and Atmospheric Administration (NOAA) Air Resources Laboratory. The site is at a latitude of $37^{\circ} 11^{\prime} 28.5^{\prime \prime} \mathrm{N}$ and a longitude of $116^{\circ} 12^{\prime} 59.4^{\prime \prime} \mathrm{W}$, and at an altitude of 2,283 m above sea level.

A second platform, referred to in this report as the brush site, is in a sparsely vegetated community of perennial grasses and high-desert scrub brush (fig. $3 B$ ). This site is dominated by rabbitbrush and characterized by a vegetation cover of about 10 to 20 percent. It lies in an open field within a small bowl-shaped valley at a latitude of $37^{\circ} 10^{\prime} 48.4 \mathrm{~N}$ and a longitude of $116^{\circ} 12^{\prime} 25.27^{\prime \prime} \mathrm{W}$, and at an altitude of 2,290 m above sea level. 

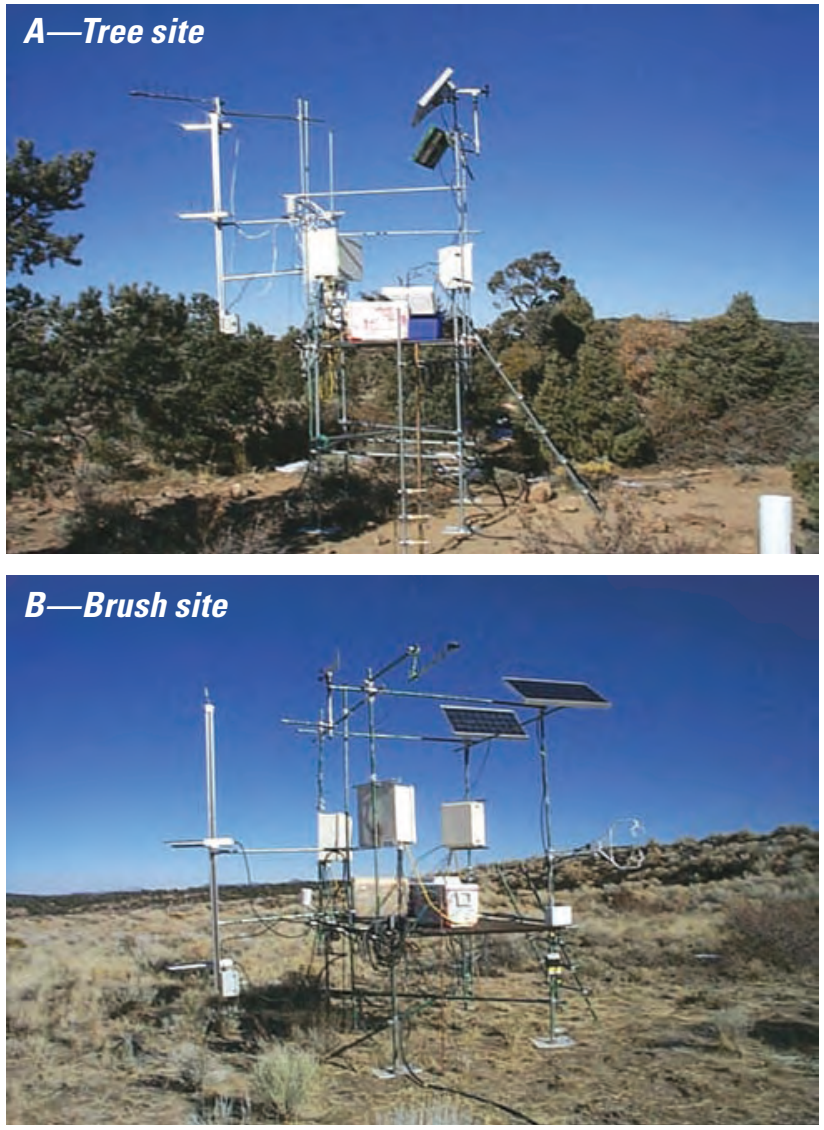

Figure 3. Photographs of $(A)$ tree and $(B)$ brush sites, Rainier Mesa, Nevada Test Site. Photograph taken by Gary Otto, U.S. Geological Survey, spring 2002.

\section{Micrometeorological and Soil Data}

Micrometeorological and soil data were collected at each platform. The data include air temperature, dewpoint temperature, and vapor pressure (measured at two heights above land surface), average relative humidity, net radiation, soil temperature, 20-minute temperature change in soil, soil heat flux (sampled at 30-second intervals), and wind speed and direction (sampled at 10-second intervals) (see appendix A). These data were used to calculate ET using the Bowen ratio method over a 20-minute period. Examples of select maximum and minimum 20-minute averaged micrometeorological data for the brush site are shown in figure 4. Periodic gaps in the data set exist due to adverse weather conditions and instrument failure.

Heat-dissipation-probe (HDP; Campbell Scientific, Inc., 1998) and water-content-reflectometer (WCR; Campbell Scientific, Inc., 1996) instrumentation were used to collect matric water potential and volumetric soil-water content data, respectively (table 1). To collect these data, three shallow holes, approximately $0.30 \mathrm{~m}$ deep were dug at each site. Two HDP sensors were placed in each hole between 0.05 and $0.20 \mathrm{~m}$ below land surface. Additionally, one WCR sensor was placed in each of the holes with the HDP sensors and inserted into the soil at about a 30 degree angle to collect data from the top $0.15 \mathrm{~m}$ of soil. In July 2004, three additional holes, approximately $12.2 \mathrm{~m}$ deep, were excavated at each site using a pneumatic rock hammer. Two HDP sensors were placed in each of these holes at about 0.46 and $1.07 \mathrm{~m}$ below land surface. These sensors were installed at greater depths than the initial HDP sensors to gain a better understanding of how water moves through the soil. Figure 5 shows the setup of the soil-water sensors in the holes. An example of volumetric soilwater content and matric water potential data at the brush site is shown in figure 6.

During the period of record (2002-05) presented in this report, 20-minute averaged airtemperature data (from the upper temperature probe) ranged from 31.8 to $-16.4^{\circ} \mathrm{C}$. The recorded maximum 20-minute averaged wind-speed data was $20.7 \mathrm{~m} / \mathrm{s}$. The daily average matric waterpotential data ranged from a maximum of -0.0001 bars to a minimum of $-10,000$ bars. The volumetric soil-water content data ranged from 99 to 6.5 percent. Annual precipitation on Rainier Mesa recorded by NOAA ranged from 85.8 to $436.0 \mathrm{~mm}$ (fig. 7). 

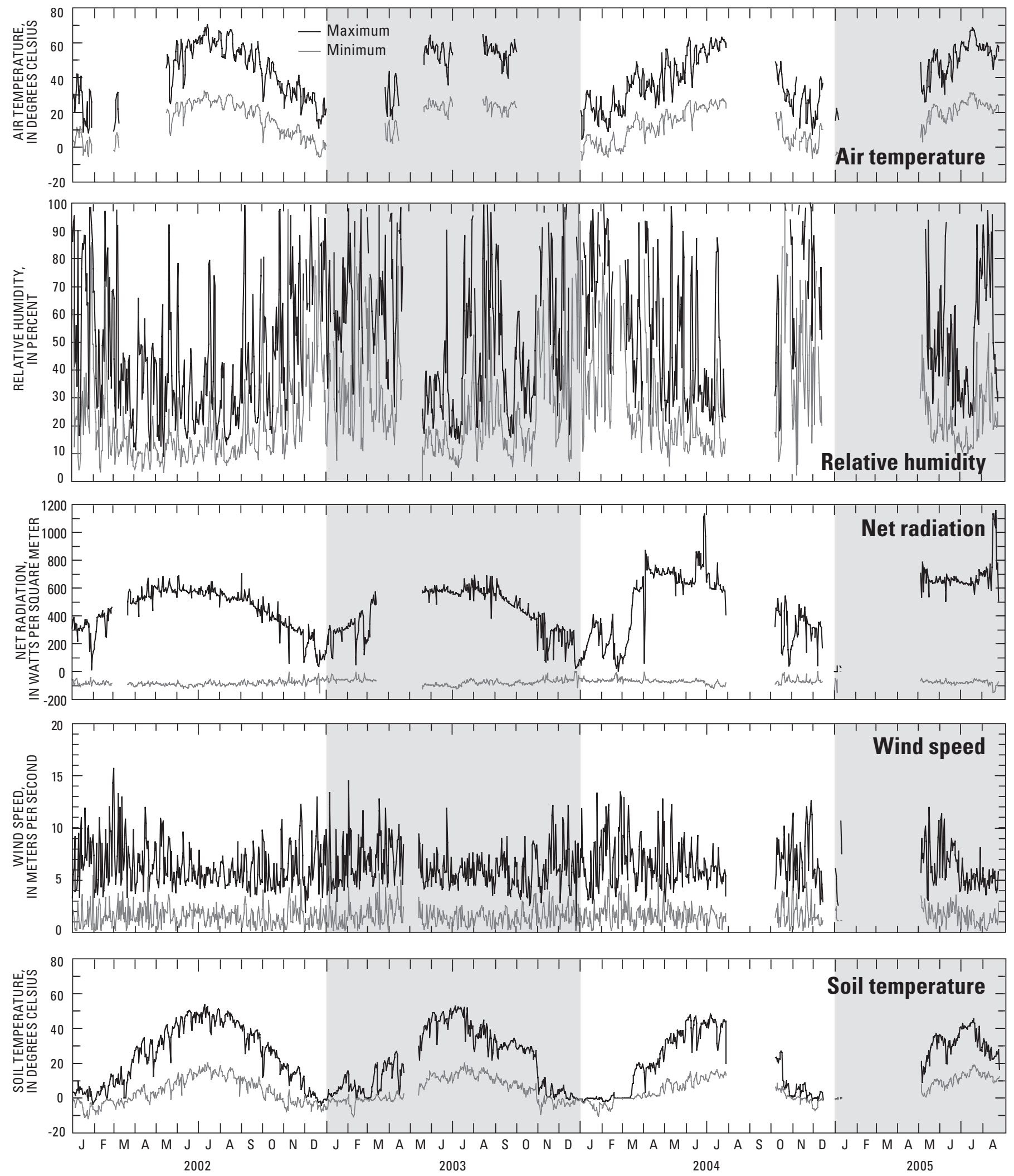

Figure 4. Examples of daily average micrometeorological data collected at brush site, Rainier Mesa, Nevada Test Site, January 1, 2002 - August 23, 2005. 

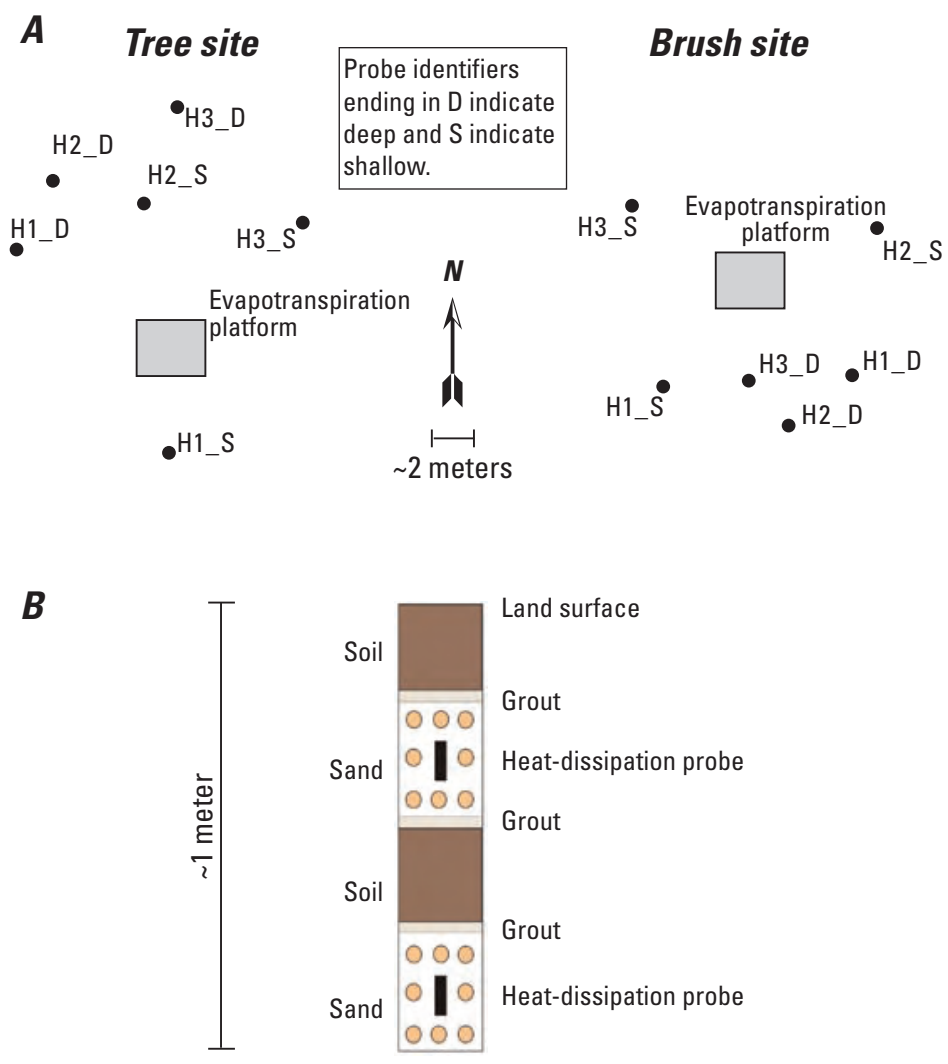

Figure 5. Schematic showing $(A)$ placement of soil-water content probes at tree and brush sites and $(B)$ vertical structure of deeper hole and placement of heat-dissipation probes used at both sites, Rainier Mesa, Nevada Test Site.
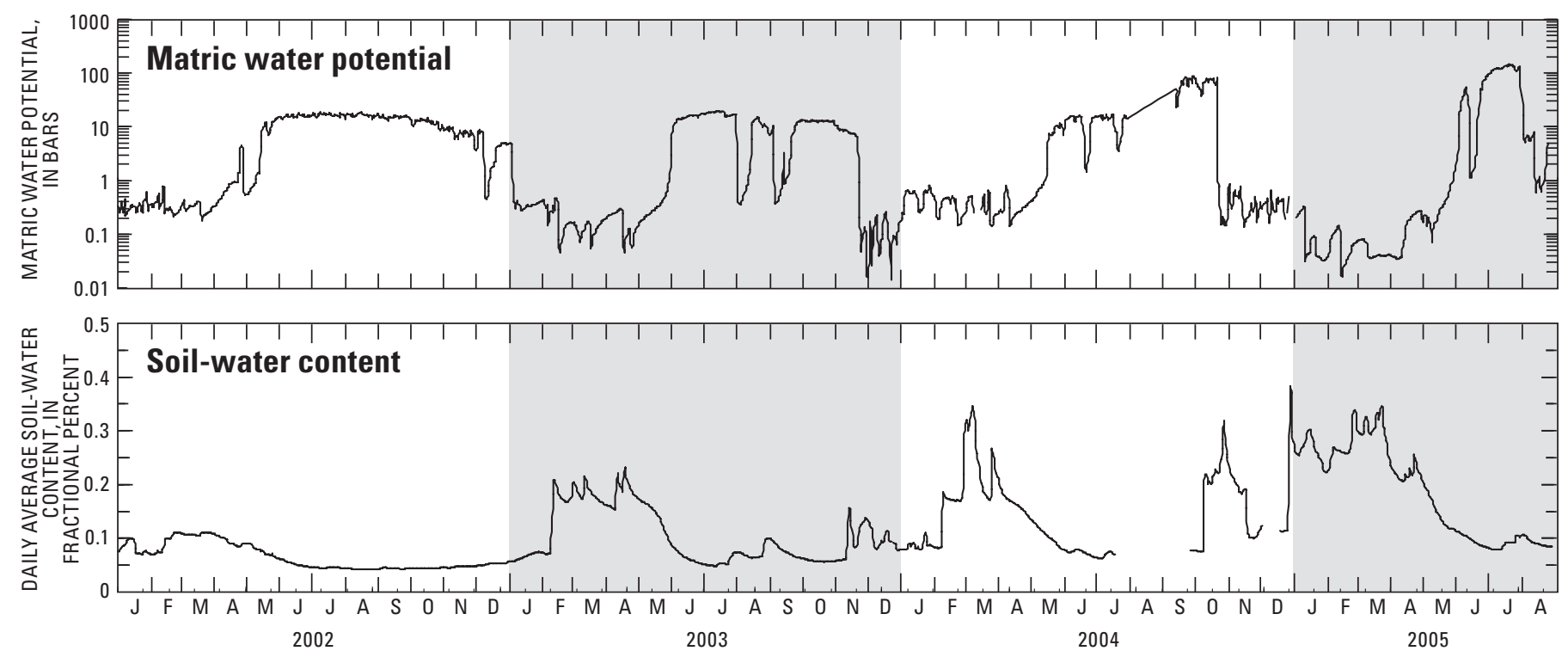

Figure 6. Daily average volumetric soil-water content and daily average matric water potential at the brush site, shallow hole 1, Rainier Mesa, Nevada Test Site, January 1, 2002 - August 23, 2005. 


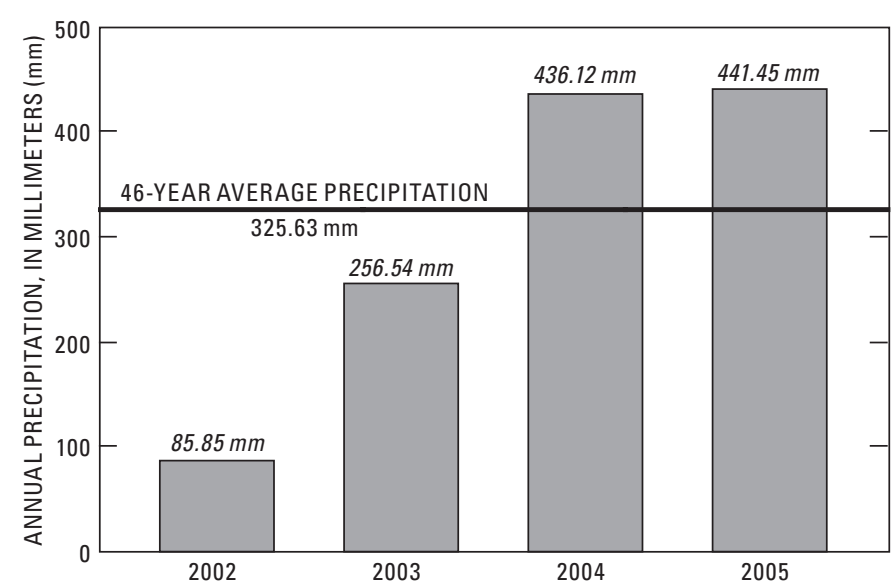

Figure 7. Total annual precipitation measured at Rainier Mesa, Nevada Test Site, 2002-05. Data are from National Oceanic and Atmospheric Administration, Special Operation and Research Division, 2006.

\section{Evapotranspiration Estimates}

Evapotranspiration is a process by which water from the Earth's surface is transferred to the atmosphere. The transfer requires that water change from a liquid to a vapor state, which consumes energy. As a result, any change in the rate of water loss by ET is reflected by a change in energy. This relation between water loss and energy consumption is the basis for many of the methods used to estimate ET. Evapotranspiration, as used in this report, includes evaporation from the soil surface, transpiration from plants, and sublimation from snowpack.

Energy at the surface of the Earth can be described as a budget, in which a balance is sought between the incoming and outgoing energy components. The available incoming or net radiation is the energy provided by the sun minus the radiation that is reflected back. This net radiation is equal to the energy used to heat the soil (soil heat flux), plus the energy used to heat the air (sensible heat flux), plus the energy used to evaporate water (latent heat flux). Terms related to the flux of energy can be expressed mathematically as:

$$
R_{n}=G_{s}+H+\lambda E,
$$

where

$R_{n}$ is net radiation, in Watts per square meter,

$G_{s}$ is soil heat flux, in Watts per square meter,

$H$ is sensible heat flux, in Watts per square meter, and

$\lambda E$ is latent heat flux, in Watts per square meter.
In this study, the Bowen ratio (Bowen, 1926) and eddy covariance (Stull, 1988) methods were applied to calculate ET rates. The Bowen ratio method requires measurements of air temperature and relative humidity at two heights above the ground. These measurements are used to calculate airtemperature and vapor-pressure gradients between the two sample heights (fig. $8 A$, table 1 ). The Bowen ratio works on the principle that the temperature and vapor-pressure gradients and the available energy regulate the latent heat flux. The eddy covariance method requires measurements of vertical wind speed and fluctuations in water vapor sampled at 0.1 -second

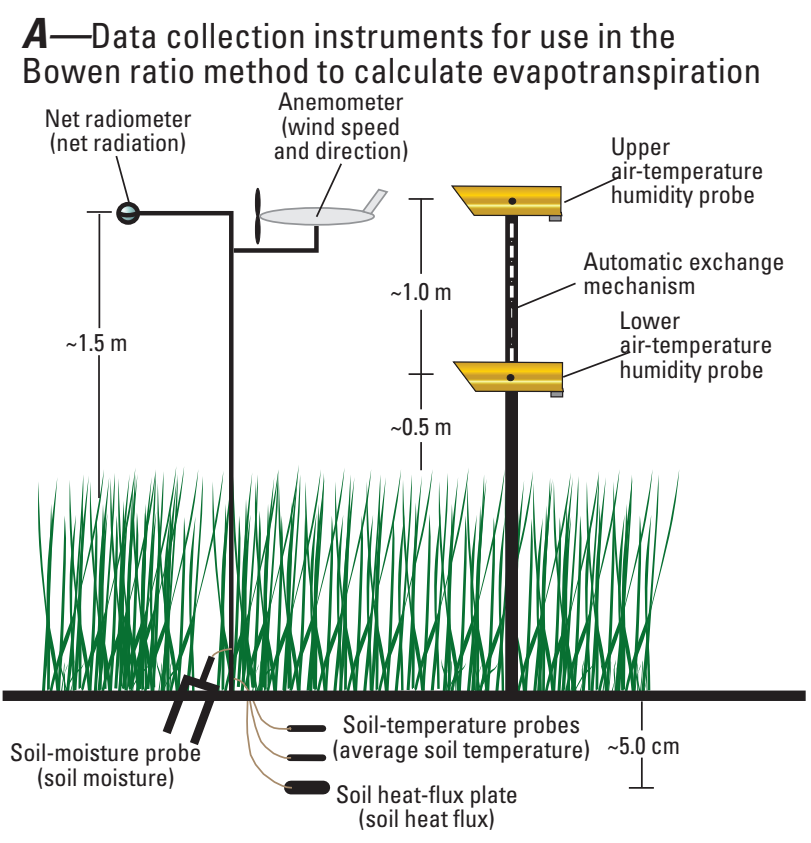

$\boldsymbol{B}$-Data collection instruments for use in the eddy covariance method to calculate evapotranspiration

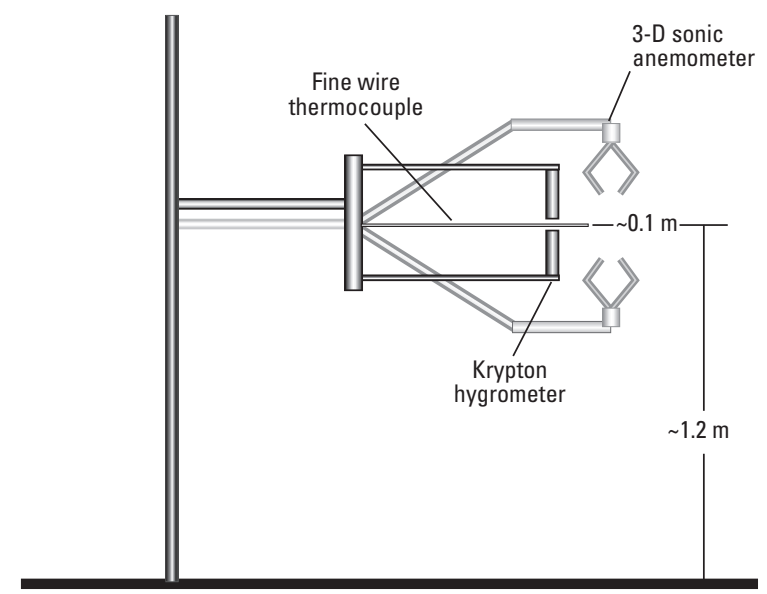

Figure 8. Schematics of $(A)$ Bowen ratio and $(B)$ eddy covariance instrumentation used at tree and brush sites on Rainier Mesa, Nevada Test Site. 
intervals using a three-dimensional sonic anemometer and a krypton hygrometer, respectively (fig. $8 B$, table 1 ). The eddy covariance method works on the principle that water vapor and heat are transported through the air by turbulence and that estimates of latent heat flux can be calculated by measuring changes in vertical wind speed, air temperature, and water vapor during short intervals of time. Corrections for temperature-induced fluctuations in air density (Webb and others, 1980) and for the sensitivity of the krypton hygrometer to oxygen (Tanner and Greene, 1989) were used to estimate latent heat flux. More detailed discussions on the Bowen ratio and eddy covariance methods are given in Laczniak and others (1999), and DeMeo and others (2003), respectively.

Numerous days of Bowen ratio data were missing at both sites due to the effects of adverse weather conditions and instrumentation failure. In 2003, the tree site was destroyed in a wind storm and no data were collected from January 4 to May 15. A more complete record of ET from the eddy covariance instrumentation was made available due to the robustness of the equipment. Data collection periods from each site, when sufficient data were available to calculate daily ET, are listed in table 2.

Daily ET using the Bowen ratio and eddy covariance methods was determined by summing 20-minute average ET rates for a 24-hour period. Calculated daily ET from 2002 to 2005 for each site is shown in figure 9. Daily ET was summed to calculate monthly and annual ET. Table 3 lists the monthly ET collected at each site during the period of record. Annual ET for the brush site using the eddy covariance method (2002-04) ranged from 243.6 to $347.5 \mathrm{~mm}$. Annual ET for the tree site using the eddy covariance method (2002 and 2004) ranged from 315.0 to $313.0 \mathrm{~mm}$.

Table 2. Number of days per month that evapotranspiration rates are available during the collection period for the Bowen ratio and eddy covariance methods at the tree and brush sites, Rainier Mesa, Nevada Test Site, January 2002 - August 2005.

[Symbol: -, missing or bad data]

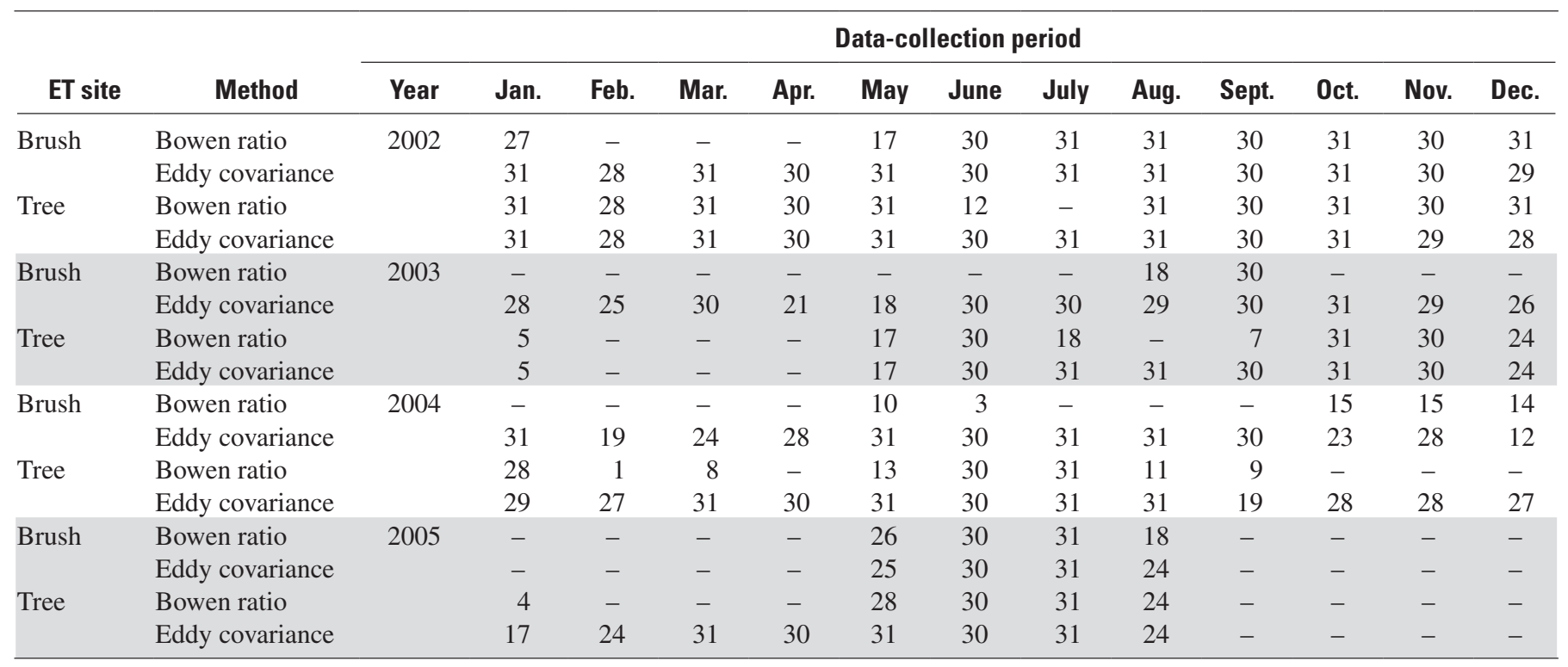



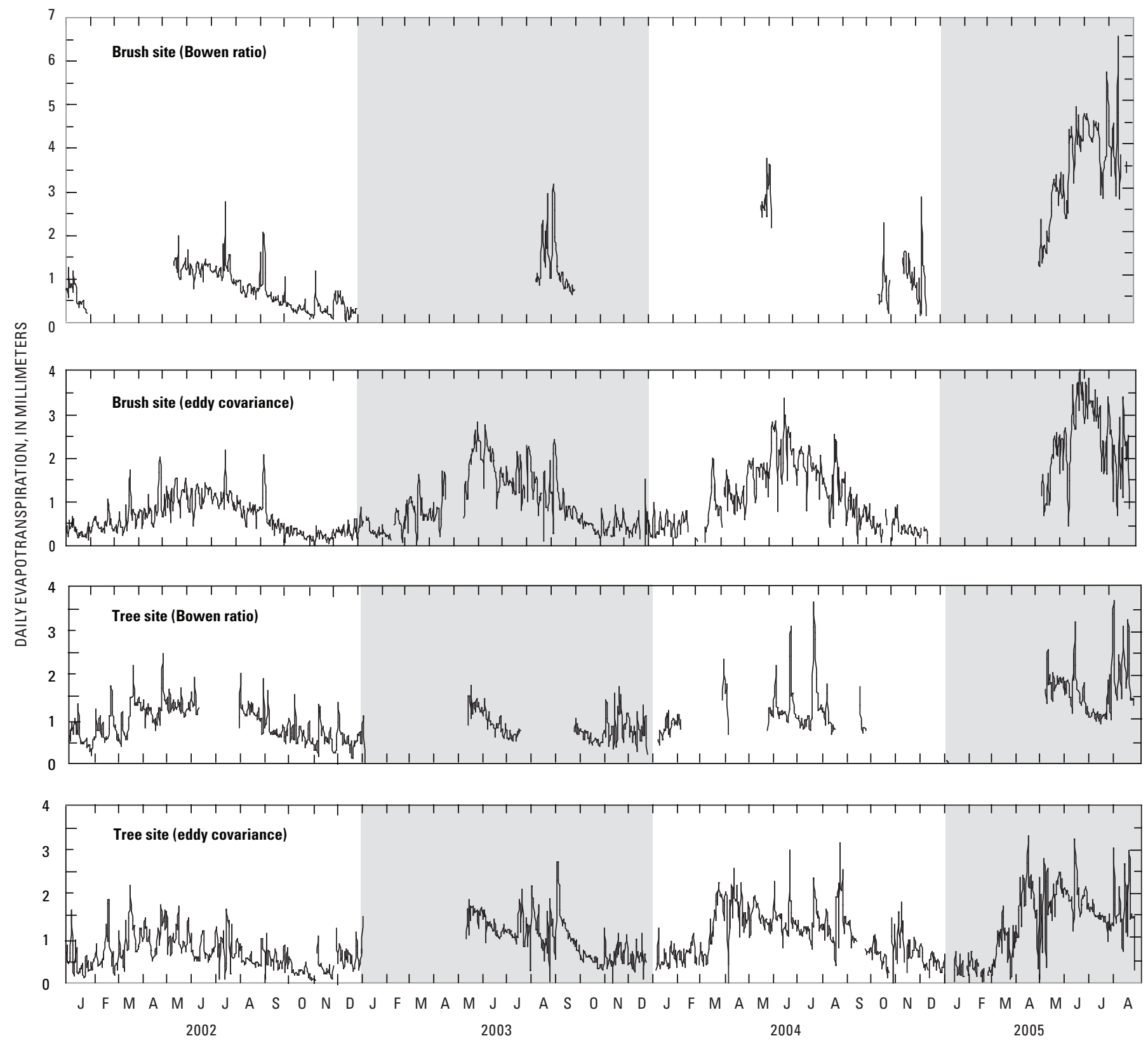

Figure 9. Daily evapotranspiration at brush and tree sites computed from data using eddy covariance and Bowen ratio methods, Rainier Mesa, Nevada Test Site, January 1, 2002 - August 23, 2005. 
Table 3. Calculated monthly evapotranspiration at the tree and brush sites, Rainier Mesa, Nevada Test Site, January 2002 - August 2005.

[Tree site/Brush site: Evapotranspiration rates only for January 1-August 23, 2005. - -, missing or bad data]

\begin{tabular}{|c|c|c|c|c|c|c|c|c|}
\hline \multirow[b]{3}{*}{ Month } & \multicolumn{8}{|c|}{ Evapotranspiration, in millimeters } \\
\hline & \multicolumn{2}{|c|}{2002} & \multicolumn{2}{|c|}{2003} & \multicolumn{2}{|c|}{2004} & \multicolumn{2}{|c|}{2005} \\
\hline & Bowen ratio & $\begin{array}{c}\text { Eddy } \\
\text { covariance }\end{array}$ & Bowen ratio & $\begin{array}{c}\text { Eddy } \\
\text { covariance }\end{array}$ & Bowen ratio & $\begin{array}{c}\text { Eddy } \\
\text { covariance }\end{array}$ & Bowen ratio & $\begin{array}{c}\text { Eddy } \\
\text { covariance }\end{array}$ \\
\hline \multicolumn{9}{|c|}{ Tree site } \\
\hline March & 32.1 & 27.0 & - & - & 13.4 & 41.1 & - & 27.2 \\
\hline April & 36.8 & 30.1 & - & - & - & 46.0 & - & 54.9 \\
\hline May & 40.2 & 32.3 & 23.4 & 27.7 & 16.5 & 47.4 & 49.6 & 59.2 \\
\hline June & 16.3 & 23.3 & 27.6 & 27.7 & 36.9 & 42.2 & 45.9 & 57.5 \\
\hline July & - & 25.0 & 11.3 & 37.5 & 41.9 & 40.6 & 42.3 & 47.5 \\
\hline November & 16.9 & 7.8 & 27.6 & 19.7 & - & 23.3 & - & - \\
\hline December & 17.4 & 18.2 & 17.2 & 13.5 & - & 10.9 & - & - \\
\hline \multicolumn{9}{|c|}{ Brush site } \\
\hline January & 16.7 & 10.6 & - & 11.0 & - & 12.8 & - & - \\
\hline February & - & 14.5 & - & 10.4 & - & 9.2 & - & - \\
\hline March & - & 18.9 & - & 24.9 & - & 20.2 & - & - \\
\hline April & - & 25.6 & - & 19.0 & - & 30.0 & - & - \\
\hline May & 22.7 & 34.0 & - & 34.5 & 31.3 & 51.3 & 63.7 & 43.9 \\
\hline June & 37.1 & 33.8 & - & 57.2 & 9.4 & 68.8 & 113.1 & 82.9 \\
\hline July & 38.8 & 34.8 & - & 44.1 & - & 56.8 & 132.6 & 90.6 \\
\hline
\end{tabular}




\section{Summary}

Micrometeorological and soil data were used to estimate daily, monthly, and annual ET rates at two instrumented sites on Rainier Mesa, January 1, 2002 - August 23, 2005. One site is in an area of brush-dominated vegetation and a second site is in an area dominated by pinyon pines and juniper trees. Micrometeorological, soil, and ET data are presented in this report in Microsoft Excel workbooks. These data include air temperature, vapor pressure, and dew point temperature at two heights; average relative humidity; net radiation; wind speed and direction; soil temperature; 20-minute temperature change in soil; soil heat flux; and ET rates. Data for both sites are presented as 20-minute averages. Volumetric soil-water content and matric water potential are presented as 1-hour intervals and daily averages.

\section{References Cited}

Bowen, I.S., 1926, The ratio of heat losses by conduction and by evaporation by any water surface: Physics Review, v. 27, p. 779-787.

Campbell Scientific, Inc., 1996, CS615 Water content reflectometer instruction manual: Campbell Scientific, Inc., $12 \mathrm{p}$.

Campbell Scientific, Inc., 1998, 229-L Soil water potential probe instruction manual: Campbell Scientific, Inc., 12 p.

DeMeo, G.A., Laczniak, R.J., Boyd, R.A., Smith, J.L., and Nylund, W.E., 2003, Estimated ground-water discharge by evapotranspiration from Death Valley, California, 1997-2001: U.S. Geological Survey Water-Resources Investigations Report 03-4254, 27 p.

Harrill, J.R., Gates, J.S., and Thomas, J.M., 1988, Major ground-water flow systems in the Great Basin region of Nevada, Utah, and adjacent states: U.S. Geological Survey Hydrologic Investigations Atlas HA-694-C, scale $1: 1,000,000,2$ sheets.
Harrill, J.R., and Prudic, D.E., 1998, Aquifer systems in the Great Basin region of Nevada, Utah, and adjacent statessummary report: U.S. Geological Survey Professional Paper 1409-A, A11 p.

Laczniak, R.J., DeMeo, G.A., Reiner, S.R., Smith, J.L., and Nylund, W.E., 1999, Estimates of ground-water discharge as determined from measurements of evapotranspiration, Ash Meadows area, Nye County, Nevada: U.S. Geological Survey Water-Resources Investigations Report 99-4079, $70 \mathrm{p}$.

National Oceanic and Atmospheric Administration, Air Resources Laboratory-Special Operation and Research Division, 2006, Overview of the climate of the Nevada Test Site (NTS): Available at URL: <http://www.sord.nv.doe. gov/raingage/Monthly/Rainer_Mesa_Monthly_Data.txt>; and available at URL: <http://www.sord.nv.doe.gov/climate/ climate.nts.general.pdf>.

Russell, C.E., Hess, J.W., and Tyler. S.W., 2001, Hydrogeologic investigations of flow in fractured tuffs, Rainier Mesa, Nevada Test Site: American Geophysical Union Monograph, v. 42, p. 105-112.

Stull, S.B., 1988, An introduction to boundary layer meteorology: Dordrecht, Netherlands, Kluwer Academic Publishers, p. 427-428.

Tanner, B.D., and Greene, J.P., 1989, Measurements of sensible heat and water vapor fluxes using eddy correlation methods: Final report prepared for the U.S. Army Dugway Proving Grounds, Dugway, Utah, 17 p.

U.S. Department of Energy, 2000, United States nuclear tests: July1945 through September 1992: Washington, D.C., U.S. Department of Energy DOE/NV-209, revision 15, 162 p.

Webb, E.K., Pearman, G.I., and Leauning, R., 1980, Correction of flux measurements for density effects due to heat and water vapor transfer: Quarterly Journal of the Royal Meteorological Society, v. 106, p. 85-100. 


\section{Appendix A: Micrometeorological, Soil, and Evapotranspiration Data Workbooks}

Micrometeorological and soil-moisture data, and evapotranspiration (ET) are presented in Microsoft Excel workbooks as part of this report. Two workbooks are available for each site; one workbook (http://pubs.water.usgs.gov/ ofr20061312/data/et.zip) contains the micrometeorological data, energy-budget fluxes, and daily ET values (calculated using both the Bowen ratio and eddy covariance methods) and the other workbook (http://pubs.water.usgs.gov/ofr20061312/ data/soil.zip) contains the soil-moisture data.

\section{Microsoft Excel workbook containing the} micrometeorological data, energy-budget fluxes, and ET include:

\section{A. Micrometeorological data worksheet (20-minute intervals):}

1. Air temperature, vapor pressure, and dew point temperature at two heights,

2. average relative humidity,

3. wind speed and direction, and

4. soil temperature, and time change in air and soil temperature.

B. Bowen ratio energy-budget fluxes and ET worksheet (20-minute intervals):

1. Net radiation,

2. sensible heat flux,

3. latent heat flux,

4. soil heat flux, and

5. ET values.
C. Eddy covariance fluxes and ET worksheet (20-minute intervals):

1. Net radiation,

2. sensible heat flux uncorrected,

3. sensible heat flux Webb (1980) corrected,

4. latent heat flux uncorrected,

5. latent heat flux Webb (1980) corrected,

6. soil heat flux, and

7. ET values.

D. ET worksheet (daily intervals):

1. Bowen ratio and

2. eddy covariance.

E. Plots of daily ET for an annual cycle:

1. Bowen ratio and

2. eddy covariance.

\section{Workbook containing soil-moisture values:}

A. Soil-moisture worksheet (hourly intervals):

1. Matric water potential and

2. volumetric water content.

B. Soil-moisture worksheet (daily average values):

1. Matric water potential and

2. volumetric water content. 
12 Micrometeorological and Soil Data for Calculating Evapotranspiration for Rainier Mesa, Nevada Test Site, 2002-05

This page is blank intentionally. 
For more information concerning the research in this report, contact the Director, Nevada Water Science Center

U.S. Geological Survey, 2730 N. Deer Run Road

Carson City, Nevada 89701

http://nv.water.usgs.gov 


\section{$\mathbb{Z}$ एक}

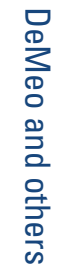

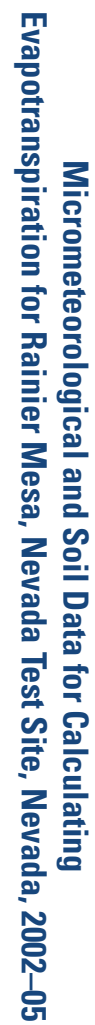

윢

옹 